Research Article

\title{
Antioxidant and Anti-Inflammatory Activities of Agrimonia pilosa Ledeb. Extract
}

\author{
Choon Young Kim $\mathbb{D}^{1},{ }^{1}$ Qi-Ming Yu $\left(\mathbb{D},{ }^{1,2}\right.$ Hyun-Joo Kong $\mathbb{D}^{3},{ }^{3}$ Joo-Yeon Lee $\mathbb{D}^{1},{ }^{1}$ \\ Kyung-Mi Yang $\mathbb{D}^{3},^{3}$ and Jung-Sook Seo $\mathbb{D}^{1}$ \\ ${ }^{1}$ Department of Food and Nutrition, Yeungnam University, Gyeongsan, Gyeongbuk 38541, Republic of Korea \\ ${ }^{2}$ Department of Nutrition and Food Hygiene, School of Public Health, Guilin Medical University, Guilin, Guangxi 541004, China \\ ${ }^{3}$ Faculty of Herbal Food Cooking \& Nutrition, Daegu Haany University, Gyeongsan, Gyeongbuk 38610, Republic of Korea
}

Correspondence should be addressed to Jung-Sook Seo; jsseo@ynu.ac.kr

Received 23 March 2020; Accepted 30 May 2020; Published 16 June 2020

Academic Editor: Carmen Mannucci

Copyright (c) 2020 Choon Young Kim et al. This is an open access article distributed under the Creative Commons Attribution License, which permits unrestricted use, distribution, and reproduction in any medium, provided the original work is properly cited.

\begin{abstract}
The purpose of this study is to investigate the effect of Agrimonia pilosa Ledeb. extract (APLE) on lipopolysaccharide- (LPS-) induced cell damage in hepatocytes with a focus on antioxidant and anti-inflammatory activities. Total antioxidant and antiinflammatory activities of APLE itself were analyzed and phytochemical analysis was performed. Moreover, inhibitory effects of APLE on LPS-induced oxidative stress and inflammation were assessed in human HepG2 hepatocytes. APLE was found to exert $\alpha, \alpha$-diphenyl- $\beta$-picrylhydrazyl (DPPH), 2,2'-azino-bis(3-ethylbenzothiazoline-6-sulphonic acid) (ABTS), and nitrite scavenging activities and reducing power in a dose-dependent manner. The total phenolic and flavonoid contents of APLE were $44.30 \pm 1.61 \mathrm{mg} \mathrm{GAE} / \mathrm{g}$ and $29.65 \pm 1.81 \mathrm{mg} \mathrm{QE} / \mathrm{g}$, respectively. HPLC analysis revealed that gallic acid is the major phenolic compound in APLE, followed by rutin, genistein, taxifolin, quercetin, luteolin, and apigenin, in descending order. Treatment of 100 and $200 \mu \mathrm{g} / \mathrm{mL}$ APLE significantly reduced LPS-stimulated intracellular reactive oxygen species production to the basal level without any cytotoxicity. Oppositely, APLE reversed LPS-suppressed expression of glutathione peroxidase gene and protein. Consistent with this result, APLE suppressed LPS-triggered expression of proinflammatory cytokine genes in a dose-dependent manner. These results reinforce the fact that the antioxidant and anti-inflammatory activity of APLE helps protect hepatocytes from LPS. Thus, APLE may be utilized as a bioactive ingredient in functional foods.
\end{abstract}

\section{Introduction}

Lipopolysaccharide (LPS), a glycolipid found in the outer membrane of the Gram-negative bacterial cell wall, is an endotoxin that causes hepatic damage and liver failure $[1,2]$. Bacterial LPS is absorbed by the intestine, enters systemic circulation, and is taken up by hepatocytes for detoxification $[1,3]$. Liver injury caused by LPS is due to increased oxidative stress and a chronic inflammatory response by proinflammatory cytokines such as tumor necrosis factor- $\alpha$ (TNF- $\alpha$ ), interleukin-6 (IL-6), and IL-1 $\beta[4,5]$.

Oxidative stress in the pathogenesis of LPS-induced hepatic damage is associated with increased generation of ROS and/or decreased levels of endogenous antioxidant enzymes including glutathione peroxidase ( $\mathrm{GpX})$, catalase, and superoxide dismutase (SOD) [6]. Oxidative stress exacerbates the inflammatory responses and vice versa [7]. Increased production of ROS enhances the inflammatory response by upregulating the genes related to immune and inflammatory cytokines through activation of the nuclear factor- $\kappa \mathrm{B}$, a redox-sensitive nuclear transcription factor [8]. Therefore, an effective way to prevent LPS-induced hepatic damage is the administration of antioxidants [9].

Accumulating evidence supports the hypothesis that individual antioxidants effectively protect the liver from LPS-induced hepatic damage. Vitamin C supplement significantly lowered LPS-induced oxidative damage in the liver of Guinea pigs [10]. Melatonin feeding in rat [11] and 
selenium treatment [4] also exhibited a hepatoprotective activity by suppressing the production of ROS and nitric oxide (NO) stimulated by LPS. $\mathrm{N}$-acetyl-l-cysteine, a precursor of glutathione, also inhibited oxidative stress stimulated by LPS $[12,13]$. Taurine administration in rats has been demonstrated to protect LPS-stimulated liver injury through antioxidant and anti-inflammatory activity [14].

Even though a single antioxidant is able to protect the liver from hepatotoxicity caused by LPS, there is an increasing interest in finding natural bioactive compounds with an ability to reduce liver damage due to their superior efficacy. Most natural antioxidants isolated from vegetables, fruits, tea, spices, and medical herbs have been demonstrated to show synergistic or additive activity because they contain multiple bioactive components [15]. Indeed, the mixture of bioactive compounds in plant extracts synergistically augments their antioxidant activity [16]. Thus, there are many efforts to investigate the protective effects of natural products against LPS-stimulated oxidative stress and inflammation. Morita et al. reported that nutmeg showed the strongest hepatoprotective potential among 21 different spices tested and they established that nutmeg extract contains multiple bioactive components, including myristicin [17]. Administration of argan oil to mice injected with LPS attenuated the oxidative stress and inflammation in the liver, as demonstrated by the improved activities of antioxidant enzymes such as Gpx, catalase, and SOD and reduced the expression of proinflammatory cytokines such as TNF- $\alpha$ and IL-6 [18].

Agrimonia pilosa Ledeb. (APL), an herbaceous perennial plant, is widely used in traditional medicine because of its multiple biological functions including anticancer, antioxidant, anti-inflammatory, and antidiabetic properties. Anticancer activity of APL has been supported by the finding that agrimoniin, a tannin found in APL, inhibited tumor growth in mice [19]. Moreover, it is believed that APL helps reduce feelings of tiredness and fatigue [20] so APL is used to treat asthenia and inflammations in allergic disease [21]. The anti-inflammatory activity of APL in macrophages has been reported due to its $\mathrm{NO}$ scavenging ability [22]. The flavonoid and triterpenoid compounds from Agrimonia pilosa Ledeb. were also reported to have showed beneficial effects on type2 diabetes mellitus by inhibiting oxidative stress and hyperglycemia [23]. Even though multiple biological functions of APL have been previously reported, the effect of APL on
LPS-induced cellular damage in hepatocytes had not yet been investigated. Thus, this study focused on determining the antioxidant and anti-inflammatory activities of APL and its bioactive compounds as well as the in vitro effect of APLE on oxidative stress and inflammation, the known pathogenic causes of hepatotoxicity.

\section{Materials and Methods}

2.1. Materials. Dulbecco's Modified Eagle's Medium (DMEM), $0.25 \%$ trypsin-EDTA, penicillin-streptomycin, sodium pyruvate, and fetal bovine serum (FBS) were purchased from Thermo Scientific (Waltham, MA, USA). Antibodies were obtained from Santa Cruz Biotechnology (Santa Cruz, CA, USA). Lipopolysaccharide (LPS), dimethyl sulfoxide (DMSO), and other reagents were purchased from Sigma-Aldrich Co. (St. Louis, MO, USA).

\subsection{Preparation of Agrimonia pilosa Ledeb. Extract (APLE).} Leaves of Agrimonia pilosa Ledeb. were purchased from a local food company in Gyeongsang in Korea. Extraction was carried out thrice by mixing Agrimonia pilosa Ledeb. (50 g) with $500 \mathrm{~mL}$ of $60 \%(\mathrm{v} / \mathrm{v})$ ethanol at $70^{\circ} \mathrm{C}$ for $3 \mathrm{~h}$, and the extract was filtered. Supernatant was evaporated at $80^{\circ} \mathrm{C}$ using a rotary evaporation concentrator (Rotavapor R-210, Buchi, Switzerland) to remove the extract solvent. The powdered form of Agrimonia pilosa Ledeb. extract (APLE) was obtained after freeze-drying (FD8512 freeze drier, ilShinbiobase Co. Ltd, Gyounggi-do, Korea). APLE was stored at $-20^{\circ} \mathrm{C}$ for further analysis.

\subsection{Determination of Total Antioxidant Capacity of APLE}

2.3.1. DPPH Radical Scavenging Activity Assay. Electron donating ability was measured using 1,1-diphenyl-2-picrylhydrazyl (DPPH) according to the method of Blois et al. [24]. Briefly, $1 \mathrm{~mL}$ of $0.2 \mathrm{mM}$ DPPH solution was added to $2 \mathrm{~mL}$ of APLE prepared for each concentration. After mixing it using a mixer for $10 \mathrm{sec}$, the mixture was incubated at $37^{\circ} \mathrm{C}$ for $30 \mathrm{~min}$. The absorbance of the reaction solution was measured using an absorption spectrophotometer (Hitachi UV-2001, Tokyo, Japan) at $517 \mathrm{~nm}$. The electron-donating ability expressed the difference in absorbance before and after sample addition in \%.

$$
\text { DPPH radical scavenging activity }(\%)=\left[1-\frac{\left(\text { Absorbance }_{\text {sample }}-\text { Absorbance }_{\text {blank }}\right)}{\text { Absorbance }_{\text {control }}}\right] \times 100 \text {. }
$$

2.3.2. ABTS Radical Scavenging Activity Assay. The ABTS scavenging activity was determined by the method of Re et al. [25]. The ABTS solution was produced by mixing $7.4 \mathrm{mM} \quad 2,2^{\prime}$-azino-bis (3-ethylbenzothiazoline-6-sulfonic acid) diammonium salt (ABTS) with $2.6 \mathrm{mM}$ potassium persulfate and then diluted with phosphate buffer saline ( $\mathrm{pH}$ 7.4) until the absorbance of the ABTS solution was $0.70 \pm 0.03$ at $732 \mathrm{~nm}$. After reacting $950 \mu \mathrm{L}$ of diluted ABTS solution with $50 \mu \mathrm{L}$ of sample for $10 \mathrm{~min}$ in the dark, the absorbance was measured at $732 \mathrm{~nm}$ using a spectrophotometer (Hitachi). The ABTS radical scavenging activity was calculated as the ratio of the decrease in absorbance between the sample and no sample. 
2.3.3. Superoxide Dismutase- (SOD-) Like Activity Assay. SOD-like activity was measured by measuring the amount of pyrogallol that catalyzes the conversion to hydrogen peroxide according to the method of Marklund et al. [26]. The reaction mixture was prepared by mixing $0.2 \mathrm{~mL}$ of sample and $3 \mathrm{~mL}$ of $50 \mathrm{mM}$ Tris- $\mathrm{HCl}$ buffer (pH 8.5) with $10 \mathrm{mM}$ EDTA and $0.2 \mathrm{~mL}$ of $7.2 \mathrm{mM}$ pyrogallol. The reaction mixture was incubated at $25^{\circ} \mathrm{C}$ for $10 \mathrm{~min}$, and then the reaction was stopped by $0.1 \mathrm{~mL}$ of $1 \mathrm{~N} \mathrm{HCl}$. Absorbance of the reaction mixture was determined at $420 \mathrm{~nm}$. SOD-like activity was calculated as the ratio of the decrease in absorbance between the sample and control.

2.3.4. Reducing Power Assay. The reducing power was measured by a modification of the method of Wong et al. [27]. To each $0.5 \mathrm{~mL}$ of sample solution, $1 \mathrm{~mL}$ of $0.2 \mathrm{M}$ phosphate buffer ( $\mathrm{pH}$ 6.6) and $1 \mathrm{~mL}$ of $1 \%$ potassium ferricyanide were added to make a reaction mixture. The reaction was allowed to proceed at $50^{\circ} \mathrm{C}$ for $30 \mathrm{~min}$ and then the mixture was cooled to room temperature, followed by adding $1 \mathrm{~mL}$ of $10 \%$ TCA solution. After incubating for $10 \mathrm{~min}, 0.5 \mathrm{~mL}$ of the reaction mixture was mixed with $1 \mathrm{~mL}$ of distilled water and $0.5 \mathrm{~mL}$ of $0.1 \% \mathrm{FeCl}_{3}$ and then the absorbance was measured at $700 \mathrm{~nm}$.

2.4. Nitrite Scavenging Ability Assay. The nitrite scavenging activity of each extract was measured according to the method of Kato et al. [28]. Specifically, the procedure was as follows: $1 \mathrm{~mL}$ of each concentration of samples was added to $2 \mathrm{~mL}$ of $1 \mathrm{mM} \mathrm{NaNO}_{2}$ solution, and the $\mathrm{pH}$ of the reaction mixture was adjusted to 1.2 and 3.0 using $0.1 \mathrm{~N} \mathrm{HCl}(\mathrm{pH} 1.2)$ and $0.1 \mathrm{M}$ citric acid buffer solution, respectively. This was followed by adjusting the final volume of the reaction mixture to $10 \mathrm{~mL}$. Then, $1 \mathrm{~mL}$ of the reaction mixture obtained by reacting at $37^{\circ} \mathrm{C}$ for $1 \mathrm{~h}$ was taken, and $5 \mathrm{~mL}$ of $2 \%$ acetic acid was added, followed by mixing with $0.4 \mathrm{~mL}$ of Griess reagent. After incubating at room temperature for $15 \mathrm{~min}$, the absorbance was measured at $520 \mathrm{~nm}$ using an absorption spectrophotometer. The nitrite scavenging activity was $(\%)=[1-(\mathrm{S}-\mathrm{B}) / \mathrm{C}] \times 100$, where $\mathrm{C}$ is the $\mathrm{ab}$ sorbance of the control, $\mathrm{S}$ is the absorbance of the sample without the Griess reagent, and B is the absorbance of the sample with the Griess reagent.

\subsection{Determination of Total Antioxidant Compounds}

2.5.1. Total Phenolic Content Assay. Total phenolic content was determined using the Folin-Ciocalteu's reagent method [29]. Gallic acid was used as a standard, and phenolic content was expressed as mg gallic acid equivalents/g (mg GAE/g).

2.5.2. Total Flavonoid Content Assay. Total flavonoid content was determined by colorimetry using the method of Moreno et al. [30]. The reaction mixture was prepared by adding $0.1 \mathrm{~mL}$ of APLE to $4.3 \mathrm{~mL}$ of $80 \%$ ethanol solution containing $10 \%$ aluminum nitrate and $1 \mathrm{M}$ potassium acetate. This reaction mixture was incubated at $25^{\circ} \mathrm{C}$ for $40 \mathrm{~min}$, and then the absorbance was measured at $415 \mathrm{~nm}$ using a spectrophotometer (Hitachi). The total flavonoid content of APLE was determined from a calibration curve obtained using quercetin as a standard.

2.6. HPLC Analytical Method of Phenolic Compounds in Agrimonia pilosa Ledeb. Extract. Phenolic compounds were analyzed by HPLC on a Shimadzu LC-20A with UV detector (SPD-20A, Shimadzu, Kyoto, Japan) and equipped with an InertSustain C18 column $(4.6 \times 250 \mathrm{~mm} ; 5 \mu \mathrm{m})(\mathrm{GL}$ Sciences, Tokyo, Japan). APLE was redissolved in methanol. All samples and standard compounds were filtrated through a $0.22 \mu \mathrm{m}$ syringe filter membrane and directly injected into the system for the analysis. The gradient elution mobile phase consisted of solvent $\mathrm{A}(0.1 \%$ acetic acid in water) and solvent $\mathrm{B}$ (methanol). The total flow rate was $1 \mathrm{~mL} / \mathrm{min}$ and the sample injection volume was $20 \mu \mathrm{L}$. Gradient elution conditions were as follows: $0-5 \mathrm{~min}, 5$ to $10 \% \mathrm{~B} ; 5-10 \mathrm{~min}, 5$ to $25 \% \mathrm{~B} ; 10-15 \mathrm{~min}, 25$ to $30 \% \mathrm{~B} ; 15-20 \mathrm{~min}, 30$ to $35 \% \mathrm{~B}$; $20-40 \mathrm{~min}, 35$ to $40 \% \mathrm{~B} ; 40-65 \mathrm{~min}, 60 \% \mathrm{~B} ; 65-110 \mathrm{~min}$, $100 \% \mathrm{~B} ; 110-115 \mathrm{~min}, 0 \% \mathrm{~B}$.

2.7. Cell Culture and Treatment Conditions. HepG2 cell, a human hepatoma cell line, was obtained from American Type Culture Collection (Manassas, VA). HepG2 cells were cultured in 10\% FBS-DMEM medium supplemented with 100 units $/ \mathrm{mL}$ penicillin and $100 \mathrm{mg} / \mathrm{mL}$ streptomycin at $37^{\circ} \mathrm{C}$ under $5 \% \mathrm{CO}_{2}$. When cell confluency reached about $80 \%$, cells were treated with APLE in the absence and presence of $100 \mathrm{ng} / \mathrm{mL}$ LPS for $24 \mathrm{~h}$.

2.8. Detection of Intracellular Oxidative Stress. A $2^{\prime}, 7^{\prime}$ dichlorofluorescein diacetate (DCFDA) assay was performed to estimate intracellular reactive oxygen species. After $24 \mathrm{~h}$ of HepG2 cells treatment with 0, 100, 200, and $400 \mu \mathrm{g} / \mathrm{mL}$ of APLE together with 0 and $100 \mathrm{ng} / \mathrm{mL}$ LPS, cells were incubated with phosphate-buffered saline (PBS) containing $120 \mu \mathrm{M}$ DCFDA for $60 \mathrm{~min}$ at $37^{\circ} \mathrm{C}$. The absorbance was determined at $488 \mathrm{~nm}$ excitation and $525 \mathrm{~nm}$ emission using a fluorescence plate reader (VICTOR X3, PerkinElmer, Turku, Singapore).

2.9. Measurement of Cell Viability by MTT Assay. Cell viability of HepG2 after treatment with APLE and with and without $100 \mathrm{ng} / \mathrm{mL}$ LPS was determined by 3-(4,5-dimethylthiazol-yl-2)-2,5-diphenyl tetrazolium bromide (MTT) assay. At the time of $60 \%$ confluence, HepG2 cells were treated with $0,100,200$, and $400 \mu \mathrm{g} / \mathrm{mL}$ APLE together with 0 or $100 \mathrm{ng} / \mathrm{mL}$ LPS for $24 \mathrm{~h}$. After aspirating the cell culture medium, cells were cultured in 10\% FBS-DMEM with $5 \mathrm{mg} /$ $\mathrm{mL}$ MTT solution. After $1 \mathrm{~h}$ of incubation, formazan, a purple product converted from a tetrazolium salts by the viable cells, was spectrophotometrically monitored at $595 \mathrm{~nm}$. Cell viability was calculated based on the following equation: 


$$
\text { cell viability }(\% \text { of control })=\frac{\left(\text { absorbance }_{\text {sample }}-\text { absorbance }_{\text {blank }}\right)}{\left(\text { absorbance }_{\text {control }}-\text { absorbance }_{\text {blank }}\right)} \times 100 \text {. }
$$

2.10. Estimation of Cell Toxicity by Lactate Dehydrogenase (LDH) Activity Assay. The cytotoxicity of HepG2 treated with APLE and LPS was determined with an LDH activity assay using a commercial test kit (Pierce LDH cytotoxicity assay kit, \#88953, Thermo Fisher Scientific, Waltham, MA, USA). LDH activity in the cell culture medium was estimated according to the manufacturer's protocol. HepG2 cells were treated with different concentrations of APLE and LPS ( 0 and $100 \mathrm{ng} / \mathrm{mL}$ ) for $24 \mathrm{~h}$ and then medium was collected for analysis. Collected medium was added to reconstituted substrate mix at room temperature for $30 \mathrm{~min}$ and then the reaction was stopped with a stop solution. The activity of $\mathrm{LDH}$ was spectrophotometrically obtained at a wavelength of $490 \mathrm{~nm}$ using a microplate reader (Epoch, BioTek, Winooski, VT, USA).

2.11. Assessment of Gene Expression Related to Inflammation and Oxidative Stress by Quantitative RT-PCR. Total RNA was extracted from HepG2 cells using TriZol reagent (Invitrogen, Carlsbad, CA, USA) and cDNA was synthesized using the SuperScript II kit (Invitrogen). Using this cDNA as a template, the gene of interest was amplified by quantitative RT-PCR using Power SYBR Green PCR master mix and thermocycler (Applied Biosystems, Foster City, CA, USA). The nucleotide sequence of the primers for human genes used in the PCR assay was as follows: tumor necrosis factor$\alpha$ (forward, $5^{\prime}$-CCC AGG CAG TCA GAT CAT CTT C-3'; reverse, $5^{\prime}$-AGC TGC CCC TCA GCT TGA-3'), interleukin6 (forward, 5'-GGT ACA TCC TCG ACG GCA TCT-3'; reverse, $5^{\prime}$-GTG CCT CTT TGC TGC TTT CAC-3'), interleukin- $1 \beta$ (forward, $5^{\prime}$-TGG CAA TGA GGA TGA CTT GTT C- $3^{\prime}$; reverse, $5^{\prime}$-CTG TAG TGG TGG TCG GAG ATT- $3^{\prime}$ ), glutathione peroxidase 1 (forward, $5^{\prime}$-GGT TTT CAT CTA TGA GGG TGT TTC C- $3^{\prime}$; reverse, $5^{\prime}$-GCC TTG GTC TGG CAG AGA CT- $3^{\prime}$ ), and $\beta$-actin (forward, $5^{\prime}$-TGA CGG GGT CAC CCA CAC TGT GCC CAT CTA-3'; reverse, $5^{\prime}$-CTA GAA GCA TTT GCG GTG GAC GAT GGA GGG-3').

2.12. Western Blot Analysis. The cells were incubated with APLE in the absence and presence of $100 \mathrm{ng} / \mathrm{mL}$ LPS for $24 \mathrm{~h}$. The cells were rinsed with ice-cold PBS, and harvested by centrifugation as previously described [31]. The cells were lysed with the lysis buffer composed of $100 \mathrm{mM}$ Tris- $\mathrm{HCl}$ buffer ( $\mathrm{pH}$ 7.5-8.0) containing $100 \mathrm{mM} \mathrm{NaCl}, 0.5 \%$ TritonX100, protease inhibitor cocktail (Sigma-Aldrich Co.), $1 \mathrm{mM}$ sodium orthovanadate, and $10 \mathrm{mM}$ sodium fluoride. The cell lysates were centrifuged to yield a clear lysate. Supernatant was collected, and protein concentration was estimated by the Bradford method (Bio-Rad Laboratories, Hercules, CA, USA). The proteins were separated by $10 \%$ SDS-PAGE and were transferred to a polyvinylidene difluoride (PVDF) membrane. The membrane was incubated for $1 \mathrm{~h}$ in blocking solution $(5 \%$ nonfat dried milk in Tris-buffered saline with $0.1 \%$ Tween 20 buffer). Immunoblot assay was performed by anti-TNF- $\alpha$ (anti-TNF- $\alpha$; Santa Cruz Biotechnology), antiGpX (anti- GpX; Santa Cruz Biotechnology), and anti$\beta$-actin (Santa Cruz Biotechnology) antibodies at $4^{\circ} \mathrm{C}$ overnight. After being washed in Tris-buffered saline with $0.1 \%$ Tween buffer, the membrane was incubated in appropriate secondary antibodies. The membrane was developed using ECL Prime Western Blotting Detection Reagent (GE Healthcare, Milwaukee, WI, USA) on X-ray film. Experiments were repeated in triplicate. ImageJ software was used to determine the band densities of proteins relative to $\beta$-actin.

2.13. Statistical Analysis. All experimental results are expressed as the mean \pm standard deviation of three independent experiments in triplicate. Statistical analysis was performed by Duncan's multiple range test after analysis of variance using Statistical Analysis System (SAS 9.4) software (SAS Institute, Cary, NC, USA). Statistical significance was tested at a level of $\alpha=0.05$. Correlations among antioxidant and anti-inflammatory activities and in vitro gene expressions were obtained by calculating Pearson's correlation coefficient.

\section{Results}

3.1. Antioxidant and Anti-Inflammatory Activities of Agrimonia pilosa Ledeb. Extract (APLE). In order to determine antioxidant activity of APLE, the free radical scavenging activity of APLE ranging from 50 to $800 \mu \mathrm{g} / \mathrm{mL}$ was determined using $\alpha, \alpha$-diphenyl- $\beta$-picrylhydrazyl (DPPH) and 2,2'-azino-bis(3-ethylbenzothiazoline-6-sulphonic acid) (ABTS) radicals. The DPPH and ABTS radical scavenging activities were increased as the concentration of APLE increased. In particular, the DPPH radical scavenging activity of APLE at $800 \mu \mathrm{g} / \mathrm{mL}$ was almost $100 \%$ (Figure 1(a)). Figure 1(b) shows that the ABTS radical scavenging activities of APLE at $400 \mu \mathrm{g} / \mathrm{mL}$ were $15.46 \pm 1.69 \%$.

As superoxide dismutase (SOD) is an important antioxidant enzyme catalyzing the dismutation of the superoxide radical into oxygen and hydrogen peroxide, determination of SOD-like activity of compounds is an appropriate method to estimate antioxidant activity. When SOD-like activity of APLE at different concentrations was measured, dose-dependent responses were observed up to $400 \mu \mathrm{g} / \mathrm{mL}$ (Figure 1(c)). APLE at 400 and $800 \mu \mathrm{g} / \mathrm{mL}$ showed approximately $68 \%$ of SOD-like activity.

The total antioxidant activity can be determined by the ferric-reducing antioxidant power assay, which is based on a redox-linked colorimetric reaction, in which ferric iron $\left(\mathrm{Fe}^{3+}\right)$ is reduced to ferrous iron $\left(\mathrm{Fe}^{2+}\right)$. The reducing power of APLE was significantly increased in a dose-dependent manner, in the range of 10 to 50 arbitrary units (Figure 1(d)). 


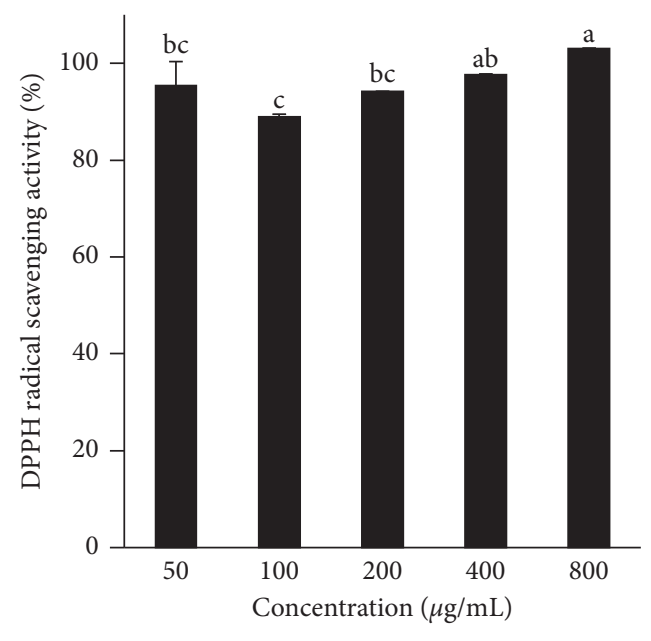

(a)

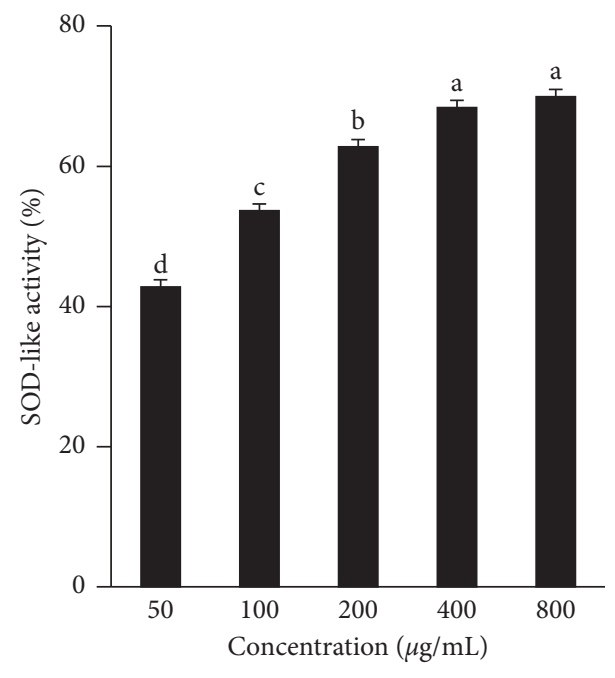

(c)

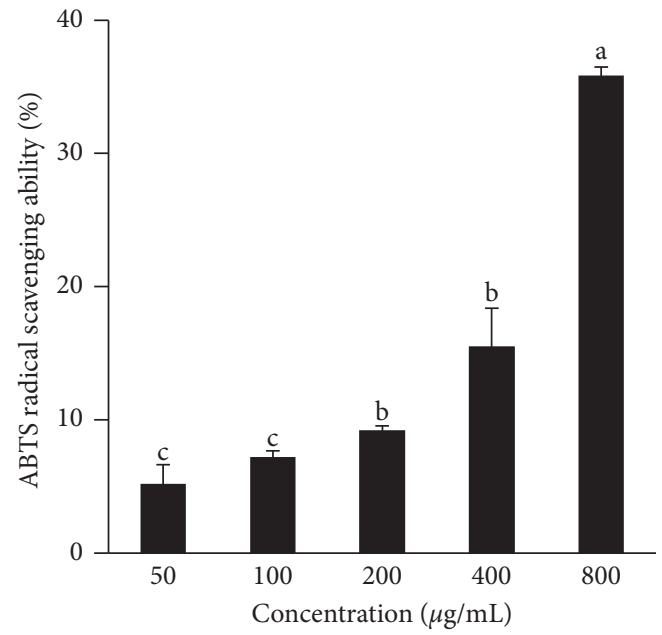

(b)

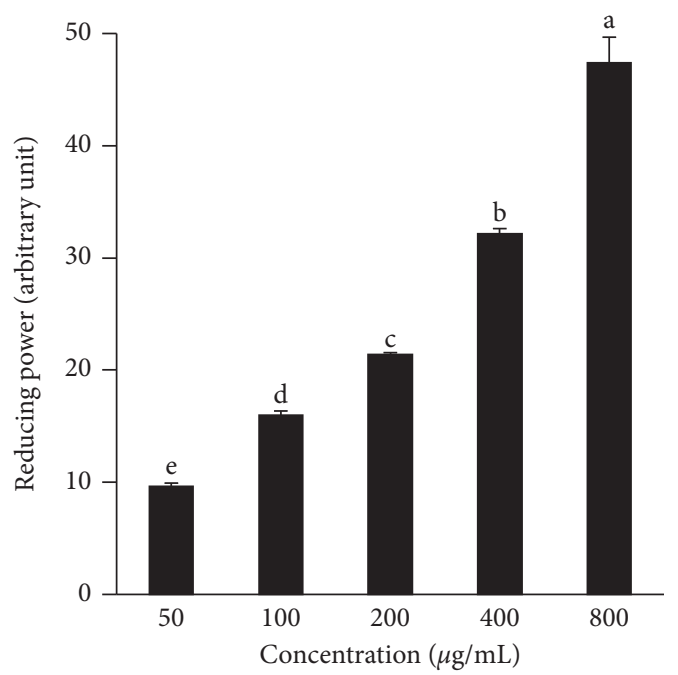

(d)

Figure 1: Antioxidant activities of Agrimonia pilosa Ledeb. extract (APLE). Free radical scavenging activities of APLE were determined by DPPH radical (a) and ABTS radical (b) scavenging activities. Superoxide dismutase- (SOD-) like activity (c) and reducing power (d) were estimated by the pyrogallol method and ferric-reducing antioxidant power assay, respectively. Values are expressed as means \pm standard deviation (SD) from three experiments. Different letters indicate a significant difference among groups $(p<0.05)$.

Nitrite $\left(\mathrm{NO}_{2}^{-}\right)$level is known to be a critical marker for inflammation [32]. As shown in Figure 2, APLE exhibited a concentration-dependent trend in its ability to scavenge nitrate. The highest nitrate scavenging activity of $73.9 \pm 3.241 \%$ was obtained at a concentration of $400 \mu \mathrm{g} / \mathrm{mL}$.

3.2. Total Phenolic and Flavonoid Contents in APLE. In order to identify the compounds responsible for the antioxidant and anti-inflammatory properties of APLE, the content of plant phenolic compounds and flavonoid and individual bioactive compounds were measured. The total phenolic and flavonoid contents in APLE were $44.30 \pm 1.61 \mathrm{mg} \mathrm{GAE} / \mathrm{g}$ and $29.65 \pm 1.81 \mathrm{mg} \mathrm{QE} / \mathrm{g}$, respectively. HPLC analysis exhibited the phenolic profile of APLE and identified seven compounds (Figure 3). The concentrations of seven phenolic compounds in APLE were the following, in descending order: gallic acid, rutin, genistein, taxifolin, quercetin, luteolin, and apigenin (Table 1). The major compound in APLE was gallic acid and its concentration was estimated at $11.27 \pm 0.63 \mathrm{mg} / \mathrm{g}$. The concentrations of rutin, genistein, taxifolin, quercetin, luteolin, and apigenin were 3.12, 2.45, $1.89,0.39,0.15$, and $0.14 \mathrm{mg} / \mathrm{g}$, respectively.

3.3. Inhibitory Effect of APLE on Lipopolysaccharide- (LPS-) Induced Oxidative Stress Without Cytotoxicity. The effect of APLE on oxidative stress was determined by dichlorofluorescein diacetate (DCFDA) assay (Figure 4). The assay is based on the oxidation of the nonfluorescent DCFH upon reaction with reactive oxygen species (ROS) to form the fluorescent DCF in HepG2 cell treated with LPS. The cells stimulated with LPS showed significantly higher intracellular reactive oxygen species (ROS) production by 1.6 folds 


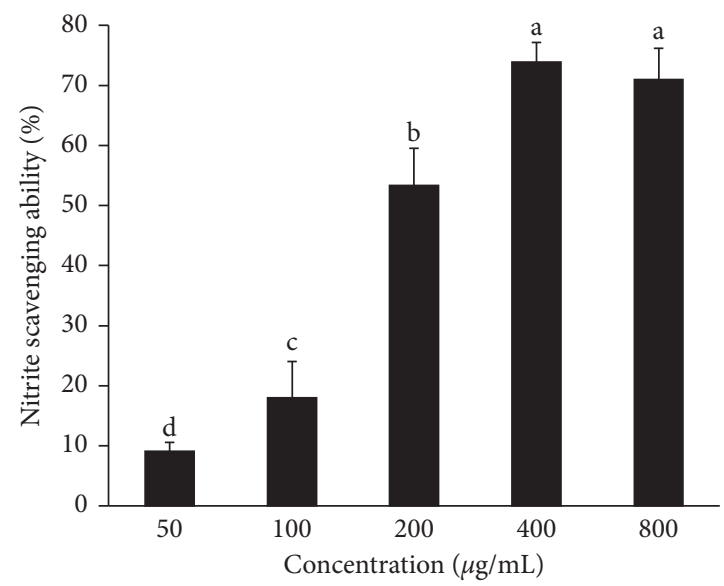

FIgURe 2: Anti-inflammatory activity of Agrimonia pilosa Ledeb. extract (APLE). The anti-inflammatory property of APLE was measured using a nitrite scavenging activity assay. Values are expressed as means \pm standard deviation (SD) from three experiments. Different letters indicate a significant difference among groups $(p<0.05)$.

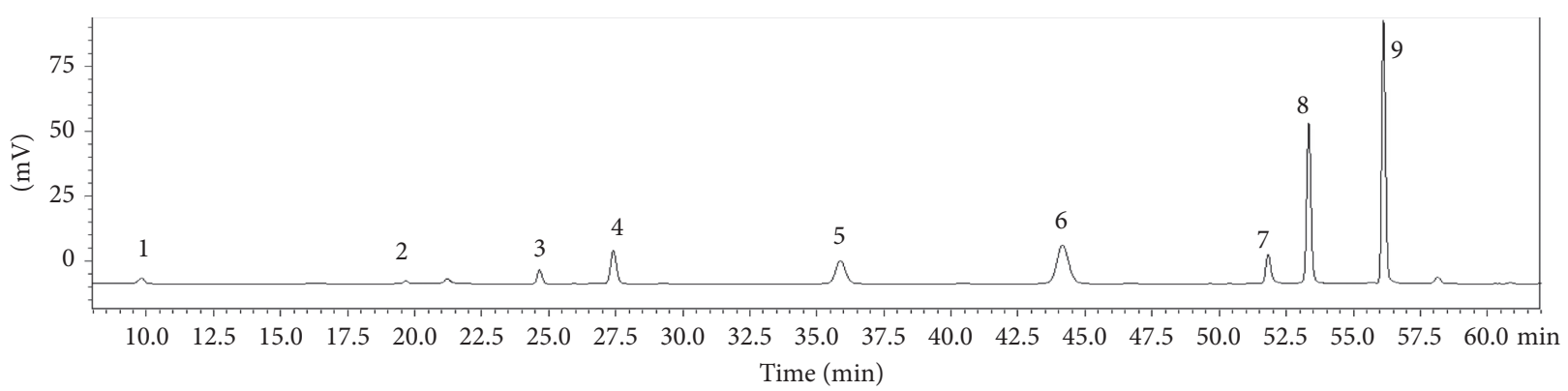

(a)

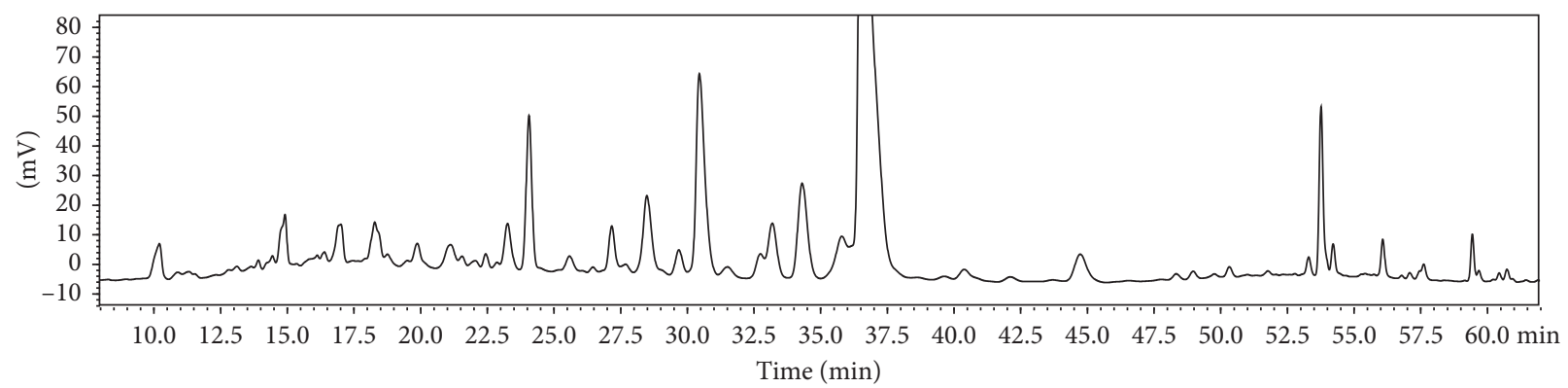

(b)

FiguRE 3: HPLC chromatogram of phenolic contents in extract of Agrimonia pilosa Ledeb. (a) Chromatogram of standard references and (b) sample. Peaks (1) gallic acid, (2) epigallocatechin gallate, (3) daidzin, (4) taxifolin, (5) rutin, (6) quercitrin, (7) luteolin, (8) quercetin, and (9) apigenin.

TABle 1: The concentration of phenolic compounds in Agrimonia pilosa Ledeb. extract.

\begin{tabular}{lc}
\hline Compounds & Concentration $^{1}(\mathrm{mg} / \mathrm{g})$ \\
\hline Gallic acid & $11.27 \pm 0.63$ \\
Rutin & $3.12 \pm 0.05$ \\
Genistein & $2.45 \pm 0.00$ \\
Taxifolin & $1.89 \pm 0.02$ \\
Quercetin & $0.39 \pm 0.00$ \\
Luteolin & $0.15 \pm 0.00$ \\
Apigenin & $0.14 \pm 0.00$ \\
\hline
\end{tabular}

\footnotetext{
${ }^{1}$ Values are means \pm standard deviation (SD).
}

compared to the nontreated cells (NT). However, APLE treatment blunted LPS-stimulated ROS generation in a dosedependent manner. ROS production in cells treated with APLE at 100 and $200 \mu \mathrm{g} / \mathrm{mL}$ without LPS was similar to that in NT. Interestingly, APLE treatment in the presence of LPS showed a slightly lower ROS level compared with NT. Cells treated with APLE at a concentration of $400 \mu \mathrm{g} / \mathrm{mL}$ had the lowest ROS levels regardless of LPS treatment. In the presence of LPS, APLE treatment at 200 or $400 \mu \mathrm{g} / \mathrm{mL}$ showed statistically similar suppression of LPS-induced ROS generation. 


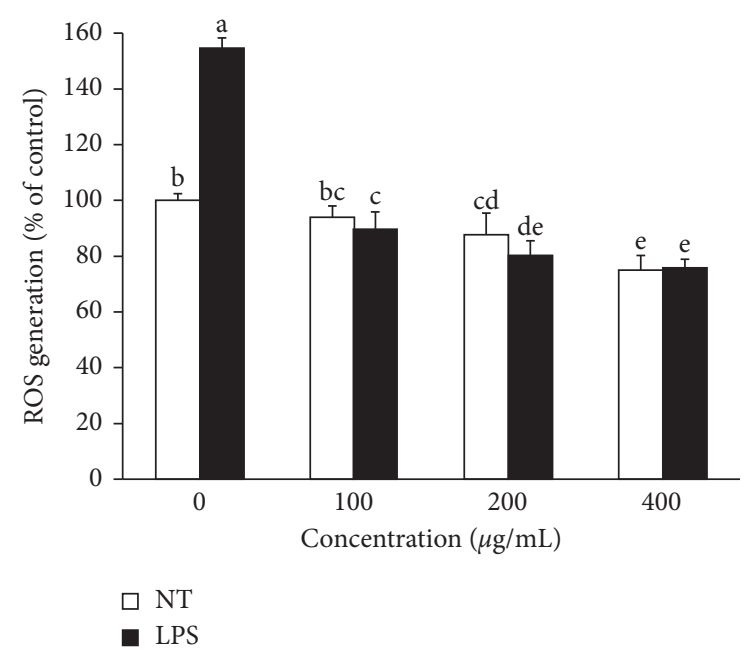

Figure 4: Effect of Agrimonia pilosa Ledeb. extract (APLE) and lipopolysaccharide (LPS) on the production of intracellular reactive oxygen species (ROS) in HepG2 cells. To assess the level of intracellular ROS, a dichlorofluorescein diacetate (DCFDA) assay was performed using HepG2 cells treated with APLE at concentrations ranging from 0 to $400 \mu \mathrm{g} / \mathrm{mL}$ in the presence and absence of $100 \mathrm{ng} / \mathrm{mL}$ of LPS for $24 \mathrm{~h}$. Means that do not share any letters are significantly different at $p<0.05$. (NT: nontreated cells).

In order to determine whether the reduction of intracellular ROS level by APLE treatment shown in Figure 4 was due to APLE cytotoxicity, cell viability and cytotoxicity were estimated in HepG2 cells treated with APLE in the absence or presence of LPS (data not shown). Without APLE treatment, LPS slightly, but not significantly, reduced cell viability. However, APLE at 100 and $200 \mu \mathrm{g} / \mathrm{mL}$ did not affect cell viability without LPS but protected cells from LPSlowered viability. Up to $200 \mu \mathrm{g} / \mathrm{mL}$ of APLE and LPS alone or in combination did not cause any cytotoxicity. Thus, the cell viability and cytotoxicity assays suggested that, regardless of the presence of LPS, concentrations of 100 and $200 \mu \mathrm{g} / \mathrm{mL}$ are safe levels for APLE treatment of HepG2 cells.

\subsection{Inhibitory Effect of APLE on LPS-Altered Expressions of} Genes and Proteins Related to Proinflammatory Cytokines and Antioxidant Enzyme. To examine the effect of APLE on LPSinduced dysregulation of gene and protein expression, quantitative RT-PCR and immunoblot analyses were carried out, respectively. As shown in Figure 5(a), the expression of proinflammatory cytokine genes, tumor necrosis factor-alpha (TNF- $\alpha$ ), interleukin-6 (IL-6), and IL- $1 \beta$ was significantly increased by more than twofold after LPS treatment, compared with corresponding the vehicle control, nontreated cells (NT). However, APLE treatment significantly lowered the gene levels of proinflammatory cytokines. On the other hand, LPS treatment significantly reduced the expression of the antioxidant enzyme glutathione peroxidase (GpX), whereas APLE increased the GpX gene expression reduced by LPS in a dose-dependent manner. Consistent with this result, protein levels of TNF- $\alpha$ in APLE treated groups were significantly lower than the LPStreated group (Figure 5(b)). LPS-suppressed GpX protein level was dose-dependently elevated by APLE treatment.
3.5. Correlation between Antioxidant and Anti-Inflammatory Activities and In Vitro Gene Expression of APLE. In order to explore the possible relationships among antioxidant and anti-inflammatory activities and in vitro gene expression, a Pearson's correlation coefficients was obtained (Table 2). Antioxidant activity assays, SOD and FRAP, were highly correlated with anti-inflammatory NO activity $(p<0.001)$. The expressions of proinflammatory genes, TNF- $\alpha$, IL- 6 and IL-1 $\beta$, were strongly correlated with each other, in which Pearson's correlation coefficients $r$ between TNF- $\alpha$ expression with both IL- 6 and IL- $1 \beta$ expression were 0.959 and 0.886 , respectively. A positive correlation between antioxidant and anti-inflammatory activities and GpX gene expression was observed, in contrast to a negative relationship between antioxidant and anti-inflammatory activities and proinflammatory gene expression.

\section{Discussion}

Compounds with antioxidant and anti-inflammatory activities may alleviate LPS-induced deterioration in hepatocytes. In hepatocytes exposed to lipopolysaccharide (LPS), the inflammatory responses are accompanied by elevated oxidative stress, leading to hepatic dysfunction and damage. Agrimonia pilosa Ledeb. extract (APLE) is known to possess a beneficial effect on human health [19-23, 33, 34]. Thus, the present study was performed to examine the effect of APLE on LPS-induced dysfunction in hepatocytes, focusing especially on oxidative stress and inflammatory responses.

Figure 4 shows that LPS causes a significant level of oxidative stress but APLE treatment significantly lowers LPS-induced intracellular reactive oxygen species (ROS) levels. It is observed that suppression of intracellular ROS levels by APLE was not relevant to the cytotoxicity of APLE. Consistent with ROS levels, the expression of gene and protein encoding glutathione peroxidase $(\mathrm{GpX})$ was significantly downregulated by LPS treatment, whereas APLE eliminated this effect and even elevated LPS-reduced GpX expression (Figure 5). In contrast, genes related to proinflammatory cytokines, such as tumor necrosis factor- $\alpha$ (TNF- $\alpha$ ), interleukin-6 (IL-6), and IL-1 $\beta$, were upregulated by LPS but APLE reversed LPS's deteriorating action.

The results of analyzing the total antioxidant and nitrite scavenging activity of APLE itself (Figures 1 and 2) verified the inhibitory effect of APLE on LPS-stimulated oxidative stress and inflammation in the cell culture system. In agreement with our results, the induction of inflammation and oxidative stress in HepG2 cells treated with LPS has been reported. Kim et al. [4] showed that APLE blocked the LPSupregulated gene expression of IL- 6 and IL- $1 \beta$, but not that of TNF- $\alpha$ [33]. The gene expression levels of antioxidant enzymes such as glutathione, $\mathrm{GpX}$, and superoxide dismutase were reduced, whereas proinflammatory cytokine IL-8 secretion and gene expression were significantly increased [35]. Meanwhile, treatment with $N$-acetyl-l-cysteine, a powerful antioxidant, inhibited LPS-induced IL-8 expression and secretion [35].

Polyphenolic compounds and flavonoids are bioactive constituents of natural products with powerful antioxidant 

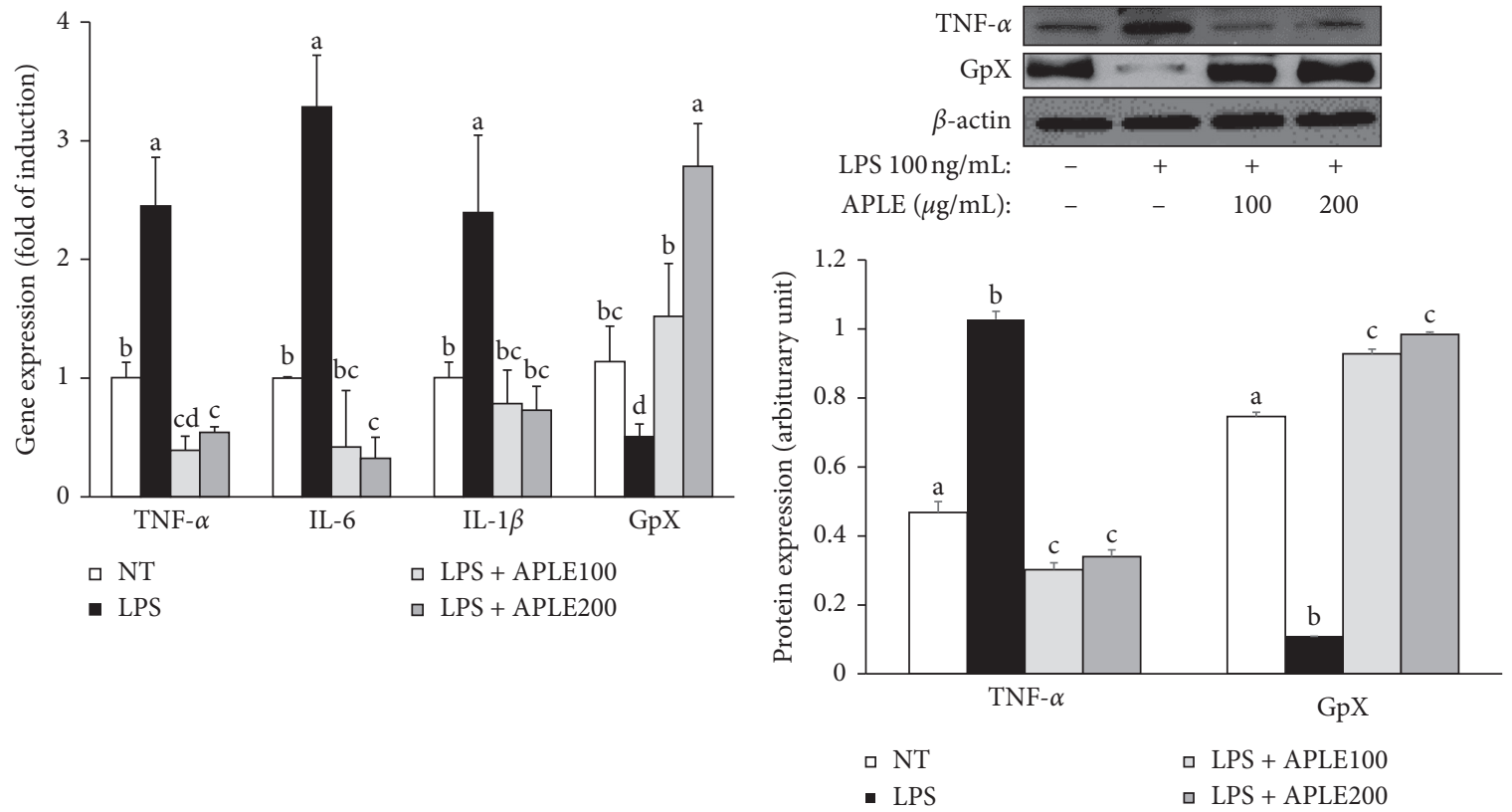

(a)

(b)

Figure 5: Effect of Agrimonia pilosa Ledeb. extract (APLE) on the levels of genes and proteins related to inflammation in lipopolysaccharide- (LPS-) induced HepG2 cells. HepG2 cells were treated with APLE $(0,100$, and $200 \mu \mathrm{g} / \mathrm{mL})$ in the presence and absence of LPS $(100 \mathrm{ng} / \mathrm{mL})$ for $24 \mathrm{~h}$. (a) Quantitative RT-PCR for the estimation of gene expression related to inflammation (TNF- $\alpha$, IL-6, and IL-1 $\beta)$ and an antioxidant enzyme, glutathione peroxidase (GpX). (b) Protein levels of TNF- $\alpha$ and GpX were assessed by immunoblot assay. The level of $\beta$-actin was shown as a loading control and used for normalization of the band intensity.

TABle 2: Pearson's correlation coefficients between the antioxidant and anti-inflammatory activities and in vitro gene expression of Agrimonia pilosa Ledeb. extract.

\begin{tabular}{|c|c|c|c|c|c|c|c|c|c|}
\hline & DPPH & ABTS & FRAP & SOD & NO & TNF- $\alpha$ & IL-6 & IL-1 $\beta$ & GpX \\
\hline DPPH & 1 & & & & & & & & \\
\hline ABTS & 0.507 & 1 & & & & & & & \\
\hline FRAP & $0.671^{* *}$ & $0.757^{* *}$ & 1 & & & & & & \\
\hline SOD & 0.429 & $0.546^{*}$ & $0.876^{* * *}$ & 1 & & & & & \\
\hline $\mathrm{NO}$ & $0.534^{*}$ & 0.455 & $0.842^{* * *}$ & $0.930^{* * *}$ & 1 & & & & \\
\hline TNF- $\alpha$ & -0.495 & -0.342 & -0.444 & -0.245 & -0.406 & 1 & & & \\
\hline IL-6 & -0.501 & -0.373 & -0.420 & -0.189 & -0.343 & $0.959^{* * *}$ & 1 & & \\
\hline IL- $1 \beta$ & -0.473 & -0.290 & -0.395 & -0.142 & -0.333 & $0.886^{* * *}$ & $0.827^{* * *}$ & 1 & \\
\hline GpX & $0.562^{*}$ & $0.530^{*}$ & $0.852^{* * *}$ & $0.714^{* *}$ & $0.728^{* *}$ & -0.349 & -0.279 & -0.307 & 1 \\
\hline
\end{tabular}

DPPH: $\alpha, \alpha$-diphenyl- $\beta$-picrylhydrazyl; ABTS: 2,2' -azino-bis(3-ethylbenzothiazoline-6-sulphonic acid); FRAP; SOD: superoxide dismutase-like activity; NO: nitrite scavenging ability; TNF- $\alpha$ : tumor necrosis factor-alpha; IL-6: interleukin-6; IL-1 $\beta$ : interleukin-1beta; GpX: glutathione peroxidase. ${ }^{*}$ Correlation is significant at $p<0.05 .{ }^{* *}$ Correlation is significant at $p<0.01$. ${ }^{* * *}$ Correlation is significant at $p<0.001$.

capacity, thus exerting protective functions against oxidative damage and providing several health benefits [36]. In accordance with results of the antioxidant activity assay, APLE contains polyphenolic compounds and flavonoids as demonstrated by the colorimetric assay. In addition, HPLC analysis revealed that APLE contains various phenolic compounds; in descending order, the concentration of phenolic compounds decreased as follows: gallic acid, rutin, genistein, taxifolin, quercetin, luteolin, and apigenin (Table 1). Differing from our data, Zhu et al. previously detected quercitrin, rutin, luteolin-7-O- $\beta$-D-glucopyranoside, taxifoliol, and hyperoside [20]. This discrepancy could be due to the difference in the extraction solvents used $(60 \%$ ethanol versus water). Even though gallic acid, the major phenolic in
APLE, has been reported to have antioxidant and anti-inflammatory functions [37], the function of APLE did not solely come from gallic acid. The combination of different phenolic and nonphenolic compounds in APLE additively and synergistically contributes to its antioxidant and antiinflammatory activities $[15,16]$.

\section{Conclusion}

Our findings suggest that APLE has the potential to prevent LPS-induced oxidative stress and inflammation due to antioxidant and anti-inflammatory activities of phenolic compounds in APLE. Therefore, APLE may be a good candidate as a functional ingredient for improving and 
maintaining liver health. Further in vivo studies are required to verify the hepatoprotective effect of APLE and to elucidate the molecular mechanisms underlying this function.

\section{Data Availability}

Experimental data used to support the findings of this study are available from the corresponding author upon request.

\section{Conflicts of Interest}

The authors declare no conflicts of interest.

\section{Acknowledgments}

This work was supported by the 2015 Yeungnam University research grant.

\section{References}

[1] J. P. Nolan, "The role of endotoxin in liver injury," Gastroenterology, vol. 69, no. 6, pp. 1346-1356, 1975.

[2] J. P. Nolan, "Intestinal endotoxins as mediators of hepatic injury-an idea whose time has come again," Hepatology, vol. 10, no. 5, pp. 887-891, 1989.

[3] E. Topchiy, M. Cirstea, H. J. Kong et al., "Lipopolysaccharide is cleared from the circulation by hepatocytes via the low density lipoprotein receptor," PLoS One, vol. 11, no. 7, Article ID e0160326, 2016.

[4] S. H. Kim, V. J. Johnson, T.-Y. Shin, and R. P. Sharma, "Selenium attenuates lipopolysaccharide-induced oxidative stress responses through Modulation of p38 MAPK and NF$\kappa \mathrm{B}$ signaling pathways," Experimental Biology and Medicine, vol. 229, no. 2, pp. 203-213, 2004.

[5] G. Wright, D. Shawcross, S. W. Olde Damink, and R. Jalan, "Brain cytokine flux in acute liver failure and its relationship with intracranial hypertension," Metabolic Brain Disease, vol. 22, no. 3-4, pp. 375-388, 2007.

[6] C. Zhang, L. M. Walker, J. A. Hinson, and P. R. Mayeux, "Oxidant stress in rat liver after lipopolysaccharide administration: effect of inducible nitric-oxide synthase inhibition," The Journal of Pharmacology and Experimental Therapeutics, vol. 293, no. 3, pp. 968-972, 2000.

[7] R. Gill, A. Tsung, and T. Billiar, "Linking oxidative stress to inflammation: toll-like receptors," Free Radical Biology and Medicine, vol. 48, no. 9, pp. 1121-1132, 2010.

[8] Y. Lavrovsky, B. Chatterjee, R. Clark, and A. Roy, "Role of redox-regulated transcription factors in inflammation, aging and age-related diseases," Experimental Gerontology, vol. 35, no. 5, pp. 521-532, 2000.

[9] S. Cadenas and A. M. Cadenas, "Fighting the stranger-antioxidant protection against endotoxin toxicity," Toxicology, vol. 180, no. 1, pp. 45-63, 2002.

[10] S. Cadenas, C. Rojas, and G. Barja, "Endotoxin increases oxidative injury to proteins in Guinea pig liver: protection by dietary vitamin C," Pharmacology \& Toxicology, vol. 82, no. 1, pp. 11-18, 1998.

[11] E. Sewerynek, D. Melchiorri, R. J. Reiter, G. G. Ortiz, and A. Lewinski, "Lipopolysaccharide-induced hepatotoxicity is inhibited by the antioxidant melatonin," European Journal of Pharmacology: Environmental Toxicology and Pharmacology, vol. 293, no. 4, pp. 327-334, 1995.
[12] R. Corinne Sprong, A. M. L. Winkelhuyzen-Janssen, C. J. Aarsman, J. F. van Oirschot, T. van der Bruggen, and B. Sweder van Asbeck, "Low-dose $N$-acetylcysteine protects rats against endotoxin-mediated oxidative stress, but high-dose increases mortality," American Journal of Respiratory and Critical Care Medicine, vol. 157, no. 4, pp. 1283-1293, 1998.

[13] A. A. Kheir-Eldin, T. K. Motawi, M. Z. Gad, and H. M. AbdElGawad, "Protective effect of vitamin E, $\beta$-carotene and $\mathrm{N}$-acetylcysteine from the brain oxidative stress induced in rats by lipopolysaccharide," The International Journal of Biochemistry \& Cell Biology, vol. 33, no. 5, pp. 475-482, 2001.

[14] Y. Liu, F. Li, L. Zhang, J. Wu, Y. Wang, and H. Yu, "Taurine alleviates lipopolysaccharide-induced liver injury by antiinflammation and antioxidants in rats," Molecular Medicine Reports, vol. 16, no. 5, pp. 6512-6517, 2017.

[15] H. Yuan, Q. Ma, H. Cui et al., "How can synergism of traditional medicines benefit from network pharmacology?" Molecules, vol. 22, no. 7, p. 1135, 2017.

[16] K. S. Sonam and S. Guleria, "Synergistic antioxidant activity of natural products," Annals of Pharmacology and Pharmaceutics, vol. 2, no. 16, pp. 1-6, 2017.

[17] T. Morita, K. Jinno, H. Kawagishi et al., "Hepatoprotective effect of myristicin from nutmeg (Myristica fragrans) on lipopolysaccharide/d-galactosamine-induced liver injury," Journal of Agricultural and Food Chemistry, vol. 51, no. 6, pp. 1560-1565, 2003.

[18] S. El Kamouni, R. El Kebbaj, P. Andreoletti et al., "Protective effect of argan and olive oils against LPS-induced oxidative stress and inflammation in mice livers," International Journal of Molecular Sciences, vol. 18, no. 10, p. 2181, 2017.

[19] K. Miyamoto, N. Kishi, and R. Koshiura, "Antitumor effect of agrimoniin, a tannin of Agrimonia pilosa Ledeb., on transplantable rodent tumors," The Japanese Journal of Pharmacology, vol. 43, no. 2, pp. 187-195, 1987.

[20] L. Zhu, J. Tan, B. Wang, R. He, Y. Liu, and C. Zheng, "Antioxidant activities of aqueous extract from Agrimonia pilosa Ledeb. and its fractions," Chemistry \& Biodiversity, vol. 6, no. 10, pp. 1716-1726, 2009.

[21] C. H. Jung, J.-H. Kim, S. Park, D.-H. Kweon, S.-H. Kim, and S.-G. Ko, "Inhibitory effect of Agrimonia pilosa Ledeb. On inflammation by suppression of iNOS and ROS production," Immunological Investigations, vol. 39, no. 2, pp. 159-170, 2010.

[22] J. Taira, H. Nanbu, and K. Ueda, "Nitric oxide-scavenging compounds in Agrimonia pilosa Ledeb. on LPS-induced RAW264.7 macrophages," Food Chemistry, vol. 115, no. 4, pp. 1221-1227, 2009.

[23] B. Na, P.-H. Nguyen, B.-T. Zhao, Q.-H. Vo, B. S. Min, and M. H. Woo, "Protein tyrosine phosphatase 1B (PTP1B) inhibitory activity and glucosidase inhibitory activity of compounds isolated from Agrimonia pilosa," Pharmaceutical Biology, vol. 54, no. 3, pp. 474-480, 2016.

[24] M. S. Blois, "Antioxidant determinations by the use of a stable free radical," Nature, vol. 181, no. 4617, pp. 1199-1200, 1958.

[25] R. Re, N. Pellegrini, A. Proteggente, A. Pannala, M. Yang, and C. Rice-Evans, "Antioxidant activity applying an improved ABTS radical cation decolorization assay," Free Radical Biology and Medicine, vol. 26, no. 9-10, pp. 1231-1237, 1999.

[26] S. Marklund and G. Marklund, "Involvement of the superoxide anion radical in the autoxidation of pyrogallol and a convenient assay for superoxide dismutase," European Journal of Biochemistry, vol. 47, no. 3, pp. 469-474, 1974.

[27] J. Y. Wong and F. Y. Chye, "Antioxidant properties of selected tropical wild edible mushrooms," Journal of Food Composition and Analysis, vol. 22, no. 4, pp. 269-277, 2009. 
[28] H. Kato, I. E. Lee, N. Van Chuyen, S. B. Kim, and F. Hayase, "Inhibition of nitrosamine formation by nondialyzable melanoidins," Agricultural and Biological Chemistry, vol. 51, no. 5, pp. 1333-1338, 1987.

[29] V. L. Singleton and J. A. Rossi, "Colorimetry of total phenolics with phosphomolybdic-phosphotungstic acid reagents," American Journal of Enology and Viticulture, vol. 16, no. 3, pp. 144-158, 1965.

[30] M. a. I. N. Moreno, M. a. I. Isla, A. R. Sampietro, and M. A. Vattuone, "Comparison of the free radical-scavenging activity of propolis from several regions of Argentina," Journal of Ethnopharmacology, vol. 71, no. 1-2, pp. 109-114, 2000.

[31] C. Kim and K.-H. Kim, "Selenate prevents adipogenesis through induction of selenoprotein $\mathrm{S}$ and attenuation of endoplasmic reticulum stress," Molecules, vol. 23, no. 11, p. 2882, 2018.

[32] P. Waltz, D. Escobar, A. M. Botero, and B. S. Zuckerbraun, "Nitrate/nitrite as critical mediators to limit oxidative injury and inflammation," Antioxidants \& Redox Signaling, vol. 23, no. 4, pp. 328-339, 2015.

[33] J.-J. Kim, J. Jiang, D.-W. Shim et al., “Anti-inflammatory and anti-allergic effects of Agrimonia pilosa Ledeb. extract on murine cell lines and OVA-induced airway inflammation," Journal of Ethnopharmacology, vol. 140, no. 2, pp. 213-221, 2012.

[34] K. J. Nho, J. M. Chun, and H. K. Kim, "Agrimonia pilosa ethanol extract induces apoptotic cell death in HepG2 cells," Journal of Ethnopharmacology, vol. 138, no. 2, pp. 358-363, 2011.

[35] L. Gómez-Quiroz, L. Bucio, V. Souza et al., "Interleukin 8 response and oxidative stress in HepG2 cells treated with ethanol, acetaldehyde or lipopolysaccharide," Hepatology Research, vol. 26, no. 2, pp. 134-141, 2003.

[36] F. Shahidi and P. Ambigaipalan, "Phenolics and polyphenolics in foods, beverages and spices: antioxidant activity and health effects-a review," Journal of Functional Foods, vol. 18, pp. 820-897, 2015.

[37] C. Pal, S. Bindu, S. Dey et al., "Gallic acid prevents nonsteroidal anti-inflammatory drug-induced gastropathy in rat by blocking oxidative stress and apoptosis," Free Radical Biology and Medicine, vol. 49, no. 2, pp. 258-267, 2010. 